\title{
SPECTRUM OF LIPID ABNORMALITY AMONG THYROID DISORDER PATIENTS IN UCMS-TH, SOUTH WESTERN REGION
}

\author{
Gautam $\mathrm{N}^{1}$, Jayan $\mathrm{A}^{1}$, Dubey $\mathrm{RK}^{1}$, Jha AC ${ }^{1}$, Sharma $\mathrm{B}^{1}$, Bohara $\mathrm{S}^{1}$, Shrestha $\mathrm{S}^{2}$
}

\begin{abstract}
INTRODUCTION:

Hypothyroidism is the most common cause of secondary dyslipidemia. Thus, thyroid function test should be carried out before starting any hypolipidemic drugs. Even among thyroid disorder, hypothyroidism is more associated with cardiovascular and associated problems and if not detected earlier, it leads to severe clinical consequences. Our study assesses the frequency and spectrum of dyslipidemia in various types of thyroidal illness in the population residing in south western part of Nepal.
\end{abstract}

\section{MATERIALS AND METHODS:}

This is a cross sectional study carried out in suspected thyroid disorder patients $(\mathrm{n}=276)$ and categorized as Euthyroidism $(\mathrm{n}=55)$, Subclinical Hypothyroidism $(\mathrm{n}=89)$, Primary Hypothyroidism $(\mathrm{n}=122)$ and Primary Hyperthyroidism $(\mathrm{n}=10)$ patients and to see the association with lipid profiles in the Department of Biochemistry, Universal College of Medical Sciences Teaching Hospital, Bhairahawa Nepal. Serum $\mathrm{fT}_{3} / \mathrm{fT}_{4}$ and TSH estimations were carried out by competitive ELISA method and Sand-wich double antibody ELISA method respectively using commercially supplied reagents (Human, Germany). The criteria for dyslipidemia was obtained by National Cholesterol Education Expert Panel/ Adult Treatment Protocol III (NCEP/ATPIII).

\section{RESULTS:}

Out of 276 cases the dyslipidemia was observed in 183 cases (66.30\%).The dyslipidemia was mostly associated with primary hypothyroidism (55.07\%) followed by Subclinical Hypothyroidism (38.04\%) than Euthyroid (5.79 \%) and Primary Hyperthyroidism (3.62\%) respectively. Out of all cases, the spectrum of dyslipidemia was mostly observed for decreased HDL $(18.5 \%)$ followed by increased TG $(10.1 \%)$. Moreover, it is significantly differ in relation in HDL $(\mathrm{p}=0.009), \mathrm{TG} / \mathrm{HDL}(\mathrm{p}=0.02)$ and Non-HDL/HDL $(\mathrm{p}=0.033)$ where as non significant as compared to other lipid profile in different groups.

\section{CONCLUSION:}

Our study revealed the close association of thyroidal illness with dyslipidemia with increased TG, low HDL, increased TG/HDL and Non-HDL/HDL. The increased TG/HDL and/or Non-HDL/HDL could be better indicator than single lipid abnormality which needs to be ascertained prospectively in large population.

KEYWORDS: Thyroid Disorders; Lipid profile; Thyroid function test; Dyslipidemia

1. Department of Biochemistry, Universal College of Medical Sciences, Bhairahawa, Nepal.

2. Lab Technologist, Paropakar Maternity and Women's Hospital, Thapathali, Nepal

\author{
Corresponding author: \\ Raju Kumar Dubey \\ Associate Professor, \\ Dept. of Biochemistry \\ Universal College of Medical Sciences \\ Bhairahawa, Nepal \\ Email:rajukd85@gmail.com
}




\section{INTRODUCTION}

Thyroid hormones stimulate the secretion of 3-hydroxy-3methylglutaryl-coenzyme A (HMG-CoA) reductase, which is the initial step in cholesterol biosynthesis. ${ }^{1}$ Thus, thyroid dysfunction can have an important effect on lipid profile .In most of cases, it was found that as the thyroid hormones decreases, total cholesterol level along with low density lipoprotein tends to increase. ${ }^{2}$ Increased levels of TC and LCL$\mathrm{C}$ was seen in subclinical hypokthyroidism. In addition , raised $\mathrm{TGs}^{4}$ as well as decreased HDL-C levels have been observed in several studies. ${ }^{5}$ Hence, screening for thyroid function test should be done while dealing patients with dyslipidemia ${ }^{6,78}$ But in patients with overt hypothyroidism, activity of HMG-CoA reductase tends to decrease while TC and LDL-C levels are increased. ${ }^{9,10}$ This can be explained as increased thyroid hormones leads to decresedcatabolism of LDL and IDL ${ }^{11,12}$ Hyperthyroidism canalso be the contributory factor that may cause unexpected improvement of lipid profile in hyperlipidemic patients ${ }^{13}$ Since, hyperthyroidism whether overt or subclinical, there is decrease in LDLand HDL cholesterol resulting enhanced oxidation of LDL that depends on level of FT4. ${ }^{14}$ Decrease in HDL-C levels is associated with increased CETP-mediated transfer of cholesteryl esters from HDL to VLDL and increased HL-mediated catabolism of $\mathrm{HDL}_{2}{ }^{15,16}$

Thyroid hormones have been positively correlated with endothelial $^{17}$ and cardiac function like atherosclerosis. ${ }^{18}$ Defects in lipid metabolism leads to the development of atherosclerotic coronary artery (CAD). ${ }^{19,20}$ CVD is not only related with the levels of LDL-C, but even depends on qualitative composition of LDL-C. ${ }^{21}$ Hence, alterations in thyroid function not only alter the serum concentration level but also result in changes in the composition and transport of lipoproteins.

Regarding HDL metabolism, thyroid hormones increase cholesteryl ester transport protein (CETP) activity. ${ }^{22} \mathrm{~T}_{3}$ upregulates LDL receptors by controlling the LDL receptors gene activation. ${ }^{23}$ Among different thyroid disorder, hypothyroidism is prevalent as one of the common causes for secondary dyslipidemia. ${ }^{24}$ Therefore, before commencing any therapy for lipid disorder, the evaluation of thyroid function is needed.

Biochemical screening for thyroid dysfunction is critical in all dyslipidemic patients as well as in all patients with unexpected improvement or worsening of their lipid profile. Hence our study can revealed the close correlation of thyroidal illness and various lipid parameters like triglycerides, cholesterol etc.. This is the first kind of study that is undertaking in southwest region of Nepal.

\section{MATERIALS AND METHODS}

A cross sectional study was conducted in Department of Biochemistry at Universal College of Medical Sciences (UCMS), Bhairahawa, Nepal. Thyroid disorders was classified as euthyroidism, TSH within the normal range, subclinical hypothyroidism, TSH $>4.7 \mathrm{mIU} / \mathrm{L}$ but normal thyroid hormones, primary hypothyroidism, TSH $>4.7 \mathrm{mIU} / \mathrm{L}$ and primary hyperthyroidism, $\mathrm{TSH}<0.5 \mathrm{mIU} / \mathrm{L}$. Only suspected thyroid disorder patients were enrolled in the study. The consent was taken from each subject and the ethical approval for the study was provided by institute review board of UCMS, Bhairahawa. Serum $\mathrm{fT}_{3}$ / fT4 and TSH estimations were carried out by competitive ELISA method ${ }^{4}$ and Sandwich double antibody ELISA method ${ }^{5}$ respectively using commercially supplied reagents (Human, Germany). The criterion for dyslipidemia was obtained by National Cholesterol Education Expert Panel/ Adult Treatment Protocol III (NCEP/ATPIII).

\section{STATISTICAL ANALYSIS}

The data were entered in IBM SPSS Windows version 22 and were expressed as mean and SD values. Independent ttest and Oneway Analysis of Variance (ANOVA) were used. Pearson's correlation coefficient was used to find association between different variables. A $P$ value $<0.05$ was considered statistically significant.

\section{RESULTS}

Out of 276 cases the dyslipidemia was observed in 183 cases $(66.30 \%)$ and 90 cases $(33.70 \%)$ were with normal lipid. Out of all cases, dyslipidemia was mostly associated with primary hypothyroidism $(52.46 \%)$, subclinical hypothyroidism $(38.26 \%)$, euthyroid $(5.46 \%)$ and primary hyperthyroidism $(3.82 \%)$ respectively. The single lipid abnormality was highest in increased LDL (49.8\%), decreased HDL (27.8\%), increased triglyceride (15.3\%) and increased Cholesterol $(7.1 \%)$ respectively.

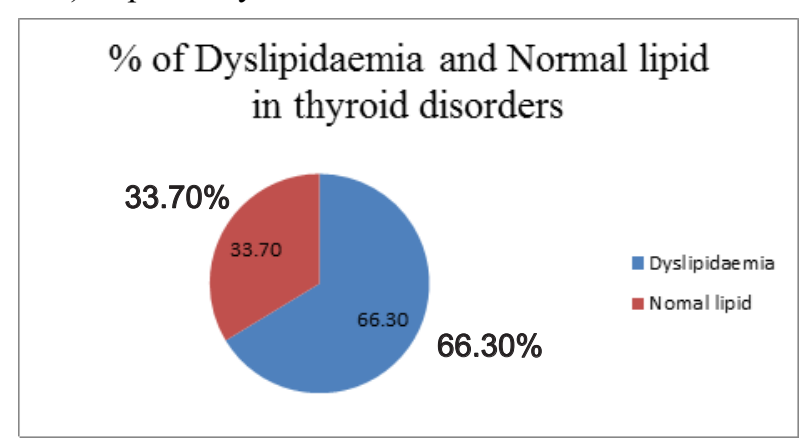

Figure 1: Distribution of Dyslipidaemia in Thyroid disorder Cases ( $\mathrm{n}=276$ ) 
Table 1: Distribution of Dyslipidemia in thyroid disorders

\begin{tabular}{|l|l|l|l|l|l|}
\hline $\begin{array}{l}\text { Variables (NCEP/ATP III) } \\
\text { for dyslipidemia }\end{array}$ & Euthyroid & $\begin{array}{l}\text { Sub Clinical } \\
\text { Hypo }\end{array}$ & $\begin{array}{l}\text { Primary } \\
\text { Hypo }\end{array}$ & $\begin{array}{l}\text { Primary } \\
\text { Hyper }\end{array}$ & Total (\%) \\
\hline rasemes & 2 & 3 & 8 & 0 & $13(7.1)$ \\
\hline TG $\geq 150 \mathrm{mg} / \mathrm{dl}$ & 2 & 13 & 11 & 2 & $28(15.3)$ \\
\hline $\mathrm{LDL} \geq 130 \mathrm{mg} / \mathrm{dl}$ & 4 & 31 & 53 & 3 & $91(49.8)$ \\
\hline HDL $<40(\mathrm{M}), 50(\mathrm{~F}) \mathrm{mg} / \mathrm{dl}$ & 2 & 23 & 24 & 2 & $51(27.8)$ \\
\hline Total & $\begin{array}{l}10 \\
(5.46 \%)\end{array}$ & $\begin{array}{l}70 \\
(38.26 \%)\end{array}$ & $\begin{array}{l}(52.46 \%) \\
(3.82 \%)\end{array}$ & $\begin{array}{l}(100 \%) \\
(103\end{array}$ \\
\hline
\end{tabular}

The maximum of dyslipidemia was seen observed in isolated decreased HDL (18.5\%), combination of increased TG and Decreased HDL (15.2\%), increased TG (10.1\%) and increased TC (4.7\%) respectively.

Table 2: Association between thyroid disorders and spectrum of lipid profile

\begin{tabular}{|l|l|l|l|l|l|}
\hline Lipid statu & Euthyroid & $\begin{array}{l}\text { SubClinical } \\
\text { Hypo }\end{array}$ & $\begin{array}{l}\text { Primary } \\
\text { Hypo }\end{array}$ & $\begin{array}{l}\text { Primary } \\
\text { Hyper }\end{array}$ & Total (\%) \\
\hline Normal lipid level & 45 & 19 & 26 & 3 & $93(33.7)$ \\
\hline Increased TG & 2 & 13 & 11 & 2 & $28(10.1)$ \\
\hline Decreased TC \& HDL & 0 & 2 & 0 & 1 & $3(1.1)$ \\
\hline Increased TC \& LDL & 1 & 2 & 5 & 1 & $9(3.3)$ \\
\hline Decreased HDL & 2 & 23 & 24 & 2 & $51(18.5)$ \\
\hline Increased TC \& TG, Decreased HDL & 0 & 3 & 4 & 1 & $8(2.9)$ \\
\hline Increased TG \& Decreased HDL & 2 & 13 & 27 & 0 & $42(15.2)$ \\
\hline Increased TC, TG \& LDL, Decreased HDL & 1 & 2 & 1 & 0 & $4(1.4)$ \\
\hline Increased TC & 2 & 3 & 8 & 0 & $13(4.7)$ \\
\hline Increased TC \& Decreased HDL & 0 & 3 & 5 & 0 & $8(2.9)$ \\
\hline Increased TG \& Decreased TC & 0 & 1 & 0 & 0 & $1(0.4)$ \\
\hline Increased TC \& TG & 0 & 5 & 6 & 0 & $11(4.0)$ \\
\hline Decreased TC & 0 & 0 & 1 & 0 & $1(0.4)$ \\
\hline Increased TC \& LDL, Decreased HDL & 0 & 0 & 4 & 0 & $4(1.4)$ \\
\hline Total & 55 & 89 & 122 & 10 & 276 \\
\hline
\end{tabular}

There were significant difference in the thyroid hormones $(\mathrm{p}<0.0001)$, HDL cholesterol $(\mathrm{p}<0.009), \mathrm{TG} / \mathrm{HDL}$ ratio $(p<0.024)$ and Non-HDL/HDL ratio $(p<0.033)$ respectively.

Table 3: Comparison of thyroid hormones and lipid profile in different thyroid disorder

\begin{tabular}{|l|l|l|l|l|l|}
\hline Variables & $\begin{array}{l}\text { Euthyroid } \\
(\mathrm{n}=55)\end{array}$ & $\begin{array}{l}\text { Sub Clinical } \\
\text { Hypo }(\mathrm{n}=89)\end{array}$ & $\begin{array}{l}\text { Primary } \\
\text { Hypo }(\mathrm{n}=122)\end{array}$ & $\begin{array}{l}\text { Primary } \\
\text { Hyper }(\mathrm{n}=10)\end{array}$ & $\begin{array}{l}\text {-value } \\
(\text { ANOVA })\end{array}$ \\
\hline fT3 & $2.52 \pm 0.56$ & $1.85 \pm 0.43$ & $1.43 \pm 0.45$ & $4.55 \pm 1.10$ & 0.0001 \\
\hline fT4 & $1.28 \pm 0.25$ & $1.05 \pm 0.26$ & $0.80 \pm 0.15$ & $2.36 \pm 0.49$ & 0.0001 \\
\hline TSH & $3.68 \pm 1.65$ & $7.85 \pm 1.07$ & $26.88 \pm 18.81$ & $0.15 \pm 0.04$ & 0.0001 \\
\hline TC & $171.38 \pm 43.31$ & $175.48 \pm 52.26$ & $173.35 \pm 56.52$ & $160.65 \pm 82.74$ & 0.148 \\
\hline TG & $144.85 \pm 26.01$ & $172.95 \pm 114.81$ & $160.92 \pm 85.66$ & $146.26 \pm 95.84$ & 0.302 \\
\hline HDL & $54.53 \pm 10.18$ & $47.11 \pm 13.10$ & $49.72 \pm 16.18$ & $43.11 \pm 10.10$ & 0.009 \\
\hline LDL & $88.30 \pm 73.97$ & $100.82 \pm 44.26$ & $93.97 \pm 44.93$ & $91.08 \pm 50.58$ & 0.187 \\
\hline VLDL & $28.96 \pm 5.18$ & $34.38 \pm 22.86$ & $32.53 \pm 17.21$ & $29.24 \pm 19.17$ & 0.329 \\
\hline TG/HDL & $2.76 \pm 0.84$ & $3.92 \pm 2.70$ & $3.62 \pm 2.22$ & $3.61 \pm 2.73$ & 0.024 \\
\hline Non-HDL/HDL & $2.15 \pm 1.01$ & $2.93 \pm 1.38$ & $2.71 \pm 1.38$ & $2.67 \pm 1.24$ & 0.033 \\
\hline & & & & & \\
\hline
\end{tabular}

There were signaificant difference in thyroid liarmone $(\mathrm{p}<0.0001)$ HDL cholesterol $(\mathrm{P}<0.0001)$, TG/HDL ration $(\mathrm{p}<0.024)$, Non HDL/HDL ration $(\mathrm{p}<0.033)$ respectively (Table 3)

Table 4:Correlation analysis of the lipid profile with thyroid hormones

\begin{tabular}{|l|l|l|l|l|l|l|l|}
\hline Variables & TC & TG & HDL & LDL & VLDL & TG/HDL & Non-HDL/HDL \\
\hline fT3 & -.35 & -.121 & 0.028 & -.008 & -.127 & -.116 & -.071 \\
\hline fT4 & -.017 & -.027 & .009 & -.001 & -0.22 & -.025 & -.030 \\
\hline TSH & .051 & .048 & -.095 & .050 & .057 & .106 & .015 \\
\hline
\end{tabular}

There were negative correlation of TC, TG, LDL, VLDL, TG/HDL, Non-HDL/HDL with fT3, fT4 and positive correlation of TC, TG, LDL, VLDL, TG/HDL, NonHDL/HDL with TSH but HDL has negative correlation with HDL. The variables observed to be not statistically significant.

\section{DISCUSSION}

Thyroid hormones play a major role in maintaining effective lipid metabolism thus any alteration in these hormone levels lead to drastic change in lipid profile. ${ }^{2}$ Out of 273 patients enrolled, dyslipidemia was mostly associated with primary hypothyroidism $(52.46 \%)$, subclinical hypothyroidism $(38.26 \%)$, euthyroid $(5.46 \%)$ and primary hyperthyroidism $(3.82 \%)$ respectively In our study, hypercholesterolemia along with high triglyceride level was found in primary hypothyroidism followed by subclinical hypothyroidism. Similar findings were also observed in the study of Keyes \&Heimberg ${ }^{25}$ and Laker \& Mayes ${ }^{26}$.Likewise LDL level was also found to be increased in hypothyroidism similar to that of fifth Tromso Study. ${ }^{27}$ As thyroid secretion decreases, there is decrease in rate of cholesterol secretion in bile thus decreased in excretion of cholesterol in faeces that eventually leads to hypercholesterolemia . Hypercholesterolemia is also associated with elevated level of low density lipoprotein (LDL) and decreased number of low density lipoprotein receptors on the liver cells. ${ }^{28}$ Decreased LDL receptors cause diminished receptor mediated catabolism of LDL. IDL is the main cause of the hypercholesterolemia observed in hypothyroidism. ${ }^{31}$ According to Nikkilia \& Kekki ${ }^{29}$, decreased in activity of lipoprotein lipase (LPL) leads to increase in triglyceride level in hypothyroidism which results in decreased clearance of triglyceride-rich lipoproteins.In other hand, there is elevated levels ofhigh density lipoprotein cholesterol (HDL-C) in hypothyroid patients due to increased concentration of HDL 2 particles. ${ }^{30}$ In our study, decresed HDL 
(47.11 \pm 13.10$)$ was found to be associated with hypothyroid cases rather than euthyroid ones suggesting a defect in HDL metabolism. Although the observation was confronting one but some of the studies also reproduce the similar results. ${ }^{1,31}$ There were significant difference in the thyroid hormones $(p<0.0001)$, HDL cholesterol $(p<0.009)$, TG/HDL ratio $(\mathrm{p}<0.024)$ and Non-HDL/HDL ratio $(\mathrm{p}<0.033)$ respectively. Our study showed that mean HDL level was significantly higher in hypothyroidism but there was no statistically significant difference in the mean LDL, VLDL, cholesterol and triglyceride levels. LDl cholesterol was higher in hypothyroid patients as compared to others . This suggest that hypothyroid patients are at high risk in developing cardiovascular diseases.

Regarding TG/HDL and Non HDL/HDL ratio, the highest average ratio was seen in subclinical hypothyroid patient $(\mathrm{p}=$ $0.024, p=0.033$ )since TG and Non HDL cholesterol were found to be markedly increased in such cases. Some studies have also shown that $\mathrm{SH}$ dyslipidemia may also be accompanied by increased TGs ${ }^{12,32}$ and decreased HDL-C levels. $^{33}$

Different parameters of lipid spectrum was found to be negatively correlated with thyroid hormones (fT3 and fT4).meanwhile positive correlation was seen with that of TSH level. Like some other studies ${ }^{34}$, HDL cholesterol was found to be negatively correlated with TSH but the variables observed to be not statistically significant.

\section{CONCLUSION}

Our study revealed the close association of thyroidal illness with dyslipidemia with increased TG, low HDL, increased TG/HDL and Non-HDL/HDL. The increased TG/HDL and/or Non-HDL/HDL could be better indicator than single lipid abnormality. Hence, biochemical screening for thyroid dysfunction is critical in all dyslipidemic patients and proper treatment in designated time will prevent the patients from future consequences of developing cardiovascular disease (CVD) like artherosclerosis.

\section{REFERENCES}

1. Bakker O, Hudig F, Meijssen S, Wiersinga WM. Effects of triiodothyronine and amiodarone on the promoter of the human LDL receptor gene.BiochemBiophys Res Commun 1998;249: 517-21

2. Liberopoulos ENEM. Dyslipidemiain patients with thyroid disorders. Hormones (Athens). 2002 Oct-Dec; 1(4):218-23. http://dx.doi.org/10.14310/horm.2002.1170

3. Danese MD, Ladenson PW, Meinert CL, Powe NR. Clinical review 115: effect of thyroxine therapy on serum lipoproteins in patients with mild thyroid failure: a quantitative review of the literature.JClinEndocrinolMetab 2000;85: 2993-3001.
4. Milionis HJ, Tambaki AP, Kanioglou CN, Elisaf MS, Tselepis $A D$, Tsatsoulis A. Thyroid substitution therapy induces highdensity lipoprotein-associated platelet-activating factoracetylhydrolase in patients with subclinical hypothyroidism: a potential antiathero-genic effect. Thyroid 2005;15: 455-60.

5. Erdem TY, Ercan M, Ugurlu S, Balci H, Acbay O, Gundogdu S. Plasma viscosity, an early cardiovascular risk factor in women with subclinical hypothyroidism.ClinHemorheolMicrocirc 2008;38: $219-25$

6. Duntas LH. Thyroid disease and lipids. Thyroid 2002;12: 28793.

7. Cooper DS. Subclinical thyroid disease: a clinician's perspective.Ann Intern Med 1998;129: 135-8.

8. Helfand M, Redfern CC. Clinical guideline, part 2. Screening for thyroid disease: an update. American College of Physicians.Ann Intern Med 1998; 129: 144-58.

9. Pearce EN, Wilson PW, Yang $O$, Vasan RS, Braverman LE. Thyroid function and lipid subparticle sizes in patients with shortterm hypothyroidism and a population-based cohort. JCl in EndocrinolMetab 2008;93: 888-94

10. Lee WY, Suh JY, Rhee EJ, Park JS, Sung KC, Kim SW. Plasma $C R P$, apolipoprotein A-1, apolipoprotein $B$ and $L p(a)$ levels according to thyroid function status.Arch Med Res 2004;35: $540-5$.

11. Walton KW, Scott PJ, Dykes PW, Davies JW. The significance of alterations in serum lipids in thyroid dysfunction. II. Alterations of the metabolism and turnover of 131-I-lowdensity lipoproteins in hypothyroidism and thyrotoxicosis. ClinSci 1965;29: 217-38

12. Abrams JJ, Grundy SM. Cholesterol metabolism in hypothyroidism and hyperthyroidism in man.J Lipid Res 1981;22: 323-38

13. Liberopoulos E, Miltiadous G, Elisaf M. Impressive lipid changes following hypolipidaemic drug administration can unveil subclinical hyperthyroidism.Diabetes Obes Metab 2001;3: 97-8.

14. Costantini F, Pierdomenico SD, De Cesare D, et al.Effect of thyroid function on LDL oxidation. Arterioscler ThrombVasc Biol 1998; 18: 732-7

15. Kung AW, Pang RW, Lauder I, Lam KS, Janus ED. Changes in serum lipoprotein(a) and lipids during treatment of hyperthyroidism.ClinChem 1995;41:226-31.

16. Aviram M, Luboshitzky R, Brook JG. Lipid and lipoprotein pattern in thyroid dysfunction and the effect of therapy.ClinBiochem 1982;15: 62-6.

17. Fernandez-Real JM, Lopez-Bermejo A, Castro A, Casamitjana $R$ Ricart $W$. Thyroid function is intrinsically linked to insulin sensitivity and endothelium-dependent vasodilation in healthy euthyroid subjects.JClinEndocrinolMetab 2006;91: 3337-43.

18. Auer J, Berent R, Weber T, Lassnig E, Eber B. Thyroid function is associated with presence and severity of coronary atherosclerosis. ClinCardiol 2003;26: 569-73.

19. Tunbridge WM, Evered DC, Hall R, et al.Lipid profiles and cardiovascular disease in the Whickham area with particular 
reference to thyroid failure. ClinEndocrinol (Oxf) 1977;7: 495508.

20. Pucci E, Chiovato L, Pinchera A. Thyroid and lipid metabolism.Int J ObesRelatMetabDisord 2000;24(Suppl 2): S109-12.

21. Third Report of the National Cholesterol Education Program (NCEP) Expert Panel on Detection, Evaluation, and Treatment of High Blood Cholesterol in Adults (Adult Treatment Panel III) final report.Circulation 2002;106: 3143-421

22. Lagrost L. Regulation of cholesteryl ester transfer protein (CETP) activity: review of in vitroand in vivostudies. Biochim BiophysActa 1994;1215: 209-36.

23. Tsimihodimos $V$, Bairaktari E, Tzallas $C$, Miltiadus $G$, Liberopoulos E, Elisaf M. The incidence of thyroid function abnormalities in patients attending an outpatient lipid clinic.Thyroid 1999;9: 365-8

24. Stone NJ. Secondary causes of hyperlipidemia.MedClin North Am 1994; 78: 117-41.

25. Keyes $W G$, Heimberg M. Influence of thyroid status on lipid metabolism in the perfused rat liver. J Clin Invest 1979;64:182190

26. Laker ME, Mayes PA. Effect of hyperthyroidism and hypothyroi -dism and carbohydrate metabolism of the perfused rat. Biochem J 1981;96:247-255.

27. Nyrnes A, Jorde R, Sundsfjord J. Serum TSH is positively associated with BMI.Int JObes (Lond) 2006;30: 100-5
28. Guyton AC, Hall JE. The thyroid metabolic hormones. In: Textbook of medical physiology. 10th edn. New York: $W$ B Saunders Company, 2000:858-868

29. Thompson GR, Soutar AK, Spengel F A, Jadhav A, Gavigan $S$ Myant NB. Defects of the receptormediated low density lipoprotein metabolism in homozygous familiar hypecholesterolemia and hypothyroidism in vivo. Proct Natl Acad Sci USA 1981;78:2591-2595.

30. Nikkilia EA, Kekki M. Plasma triglyceride metabolism in thyroid disease. JClin Invest 1972;51:2103-14.

31. Heimberg M, Olubadewo JO, Wilcox HG. Plasma lipoproteins and regulation of hepatic metabolism of fatty acids in altered thyroid states. Endocrine Rev 1985;6:590-607.

32. Milionis HJ, Tambaki AP, Kanioglou CN, Elisaf MS, Tselepis $A D$, Tsatsoulis A. Thyroid substitution therapy induces highdensity lipoprotein-associated platelet-activating factor-acetyl hydrolase in patients with subclinical hypothyroidism: a potential antiatherogenic effect. Thyroid 2005;15: 455-60.

33. Toruner F, Altinova AE, Karakoc A, et al.Risk factors for cardiovascular disease in patients with subclinical hypothyroidism. AdvTher 2008;25: 430-7.

34. Erdem TY, Ercan M, Ugurlu S, Balci H, Acbay O, Gundogdu S Plasma viscosity, an early cardiovascular risk factor in women with subclinical hypothyroidism.Clin Hemorheol Micro circ 2008; $38: 219-25$ 